\title{
Biochemical changes in fiber naturally colored cottonseeds during storage ${ }^{1}$
}

\author{
Andréa dos Santos Oliveira ${ }^{2 *}$, Maria Laene Moreira de Carvalho ${ }^{3}$, \\ Cláudio das Neves Vieira Bárbara ${ }^{3}$, Renato Mendes Guimarães ${ }^{3}$, \\ João Almir Oliveira ${ }^{3}$, Diego de Sousa Pereira ${ }^{3}$
}

\begin{abstract}
The cotton seeds deterioration process with different chemical composition, in distinct environments is essential to the definition of adequate methods for storage. The deterioration involves cellular, metabolic and chemical changes and the behavior of the seeds' antioxidant defense system has an important role to control the speed and intensity of this process. The colored fiber of cottonseeds cv. BRS Verde and white fiber cv. BRS 187-8H were stored under controlled environment conditions $\left(10^{\circ} \mathrm{C}, 25^{\circ} \mathrm{C}\right.$ and $\left.30^{\circ} \mathrm{C}\right)$ for one year. The seeds were assessed for physiological quality, presence of microorganisms, chemical composition, oil and tocopherol contents by 90 day intervals. The cottonseed physiological potential began to decrease on day 90 particularly when the storage is carried out at 25 to $30{ }^{\circ} \mathrm{C}$. Changes in lipid content and tocopherol are associated with the reduction of physiological quality. At temperatures above $25^{\circ} \mathrm{C}$ the deterioration of cottonseeds is improved and decreases their physiological quality. Reduction in fat content and tocopherol and an increase in acidity and peroxide indicate loss of quality during storage.
\end{abstract}

Index terms: Gossypium hirsutum, seed deterioration, germination, vigor.

\section{Alterações bioquímicas em sementes naturalmente coloridas de algodão durante o armazenamento}

\begin{abstract}
RESUMO - O processo de deterioração de sementes de algodão com diferenças na composição química, em ambientes distintos, é fundamental para a definição de métodos adequados para o armazenamento. A deterioração envolve alterações celulares, metabólicas e químicas e o comportamento do sistema de defesa antioxidante das sementes tem papel importante para controlar a velocidade e a intensidade desse processo. Sementes de algodão de fibra colorida cultivar BRS Verde e de fibra branca cultivar BRS $187-8 \mathrm{H}$ foram armazenadas em ambientes controlados, a $10{ }^{\circ} \mathrm{C}, 25{ }^{\circ} \mathrm{C}$ e $30{ }^{\circ} \mathrm{C}$ durante um ano. A cada 90 dias foram avaliados a qualidade fisiológica, sanitária e a composição química das sementes, do óleo e a determinação do teor de tocoferol. O potencial fisiológico das sementes decresceu a partir de 90 dias, principalmente quando realizado a 25 e $30{ }^{\circ} \mathrm{C}$. A variação no teor de lipídios e tocoferol está associada à redução da qualidade fisiológica durante a deterioração das sementes. A conservação de sementes de algodão acima de $25{ }^{\circ} \mathrm{C}$ é prejudicada, com redução na qualidade fisiológica. Decréscimos no teor de lipídios e tocoferol e aumento da acidez e peróxidos indicam perda da qualidade das sementes de algodão durante o armazenamento.
\end{abstract}

Termos para indexação: Gossypium hirsutum, deterioração de sementes, germinação, vigor.

\section{Introduction}

The production of naturally colored cotton is currently expanding in part to avoid the use of chemicals involved for fiber dyeing. Increasing the production of lint and keeping the product competitive in the market requires high quality seeds.

The cottonseeds production system is hampered by natural deterioration of seeds within the boll, by the delinting process and by the high incidence of microorganisms, which

${ }^{1}$ Submitted on 11/07/2015. Accepted for publication on $05 / 11 / 2016$.

${ }^{2}$ Departamento de Agronomia Universidade do Estado de Mato Grosso, 78200000- Cáceres, MT - Brasil. can affect physic and physiological seed quality from the beginning of storage until the time of sowing. To understand the process of seed deterioration, it is important to investigate the mechanisms and events related to the loss of viability and vigor, such as chromosome damage, decrease of enzymatic activity, degradation of respiratory and membrane system (Giurizatto et al., 2012). Chemical composition is another aspect that should be considered regarding the physiological quality of cottonseeds during storage because of their high

${ }^{3}$ Departamento de Agricultura, UFLA, Caixa Postal 3037, 37200-000 Lavras, MG, Brasil.

*Corresponding author $<$ andrea.santos.oliveira@unemat.br $>$ 
oil and protein contents. In the seeds, lipids are stored as triglycerides, which are converted into glucose for use as energy sources, producing sugars necessary for nutrition of the embryo and support germination via the processes of beta-oxidation, glyoxylate cycle and gluconeogenesis (Quettier and Eastmond, 2009).

During storage, triglycerides can have a peroxidation, increasing the content of free fatty acids and accelerating the deterioration of oilseeds (Balešević-Tubić et al., 2007). Thus, the content of free fatty acids (FFAs) can induce loss of vigor and a reduction in germination and can increase seedling abnormalities. Apart from FFAs, other markers of oil quality that may be associated with seed quality include the formation of peroxides, which accelerate the deterioration (José et al., 2010).

There is an inverse relation between lipid oxidation and seed performance during seed deterioration, mainly due to factors that interfere with respiration. Thus, the inverse action of natural antioxidants, such as tocopherol, may occur blocking the oxygen uptake by seed tissues, protecting the polyunsaturated fatty acids from peroxidation (Giurizatto et al., 2012). In cottonseeds the tocopherol content can range from 237 to $674 \mathrm{mg} . \mathrm{kg}^{-1}$, depending on the cultivar used and on the growing and storage conditions. The effect of tocopherol in seeds remains poorly understood, but it is known that there is a relationship between tocopherol content and seed storability (Sattler et al., 2004).

The color of cotton fibers may be related to the tocopherol content present in the plant and transferred to the seeds. So far, no relationship has been established between tocopherol content and oil quality in cottonseeds with different fiber colors throughout storage. The objective of this study was to obtain information on the cottonseed vigor as a result of changes in chemical composition as affected by seed storage in different environments.

\section{Material and Methods}

The Research was performed at Seed Analysis, Seed Pathology and at Biodiesel Plant Laboratories from Federal University of Lavras, state of Minas Gerais, Brazil. Seeds from cotton cultivars BRS Verde and BRS 187-8H from 2009 harvest, produced by Embrapa Algodão, located in Campina Grande, state of Paraíba.

Seeds from each cultivar were homogenized, divided in a centrifugal homogenizer, packed in multiwall paper bags and stored in controlled temperature chambers at $10^{\circ} \mathrm{C}$ (with controlled temperature and relative humidity), $25{ }^{\circ} \mathrm{C}$ and $30{ }^{\circ} \mathrm{C}$ (with controlled temperature). Initially and each 90 days during 360 days, seeds were assessed for physiological quality and presence of microorganisms and physicochemical characteristics oil.

Seed moisture content (MC) was determined as described in the Rules for Seed Testing (Brasil, 2009).

Germination test - eight replications of 25 seeds each, were used on germitest paper moistened with distilled water in the amount of 2.5 times the weight of the dry paper, and kept in a germination chamber at $25{ }^{\circ} \mathrm{C}$. First germination count was performed on the fourth day and in the final count at twelve days after sowing. The results were expressed in percentage of normal seedlings (Brasil, 2009).

Emergence - sowing in substrate mixture of soil and sand at a ratio of $1: 2$, moistened to $60 \%$ of water holding capacity in plastic boxes. The boxes were placed in a plant growing chamber at $25^{\circ} \mathrm{C}$ with 12 hour of photoperiod. Four replicates of 50 seeds per treatment were used, and the results were expressed in percentage of normal seedlings on the fourteenth day. Data of emergence speed index was performed by daily counts from the beginning of seedling emergence until stabilization of the stand, following the methodology proposed by Maguire (1962). The results were expressed in percentage.

The sanitary quality was performed using the filter paper method or Blotter test, according to the recommendations proposed by Rules for Seed Testing (Brasil, 2009).

The oil content and lipids in the seeds were extracted using the Soxhlet method, according to the recommendations proposed by the Association of Official Analytical Chemists (AOAC, 1995).

To determine the physicochemical properties of the oil was used 100 grams of ground seeds to oil extraction in a Soxhlet apparatus for 24 hours, under reflux, using n-hexane as a solvent. A Büchi-144 rotary evaporator was used to remove the $n$-hexane under reduced pressure. The oil obtained from each sample was placed in an oven at approximately $35^{\circ} \mathrm{C}$ for 24 hours to completely evaporate the solvent. Extraction was performed in triplicate. After obtaining the oil, the acidity and peroxide index were determined according to AOCS (1990).

Fatty acid composition - the seeds were ground in a cold mill with the addition of liquid nitrogen, and extraction was performed during eight hours in a Soxhlet apparatus using hexane as the solvent at temperature of $45{ }^{\circ} \mathrm{C}$ and with protection from light. The solvent was removed on a rotary evaporator at $45{ }^{\circ} \mathrm{C}$, and samples were frozen at $-20{ }^{\circ} \mathrm{C}$ until perform the analysis. Oil esterification was performed following the method described by Hartman and Lago (1973).

Composition analysis and quantification of fatty acids were performed by gas chromatography (SHIMADZU gas chromatograph, Model GC-2010) with a flame ionization 
detector and a fused silica capillary column $100 \mathrm{~m}$ in length and $0.25 \mathrm{~mm}$ in internal diameter, containing polyethylene glycol as the liquid stationary phase (SUPELCO SP ${ }^{\mathrm{TM}} 2560$ Capillary GC Column). A mixture of 37 methyl esters was used as the standard (SUPELCO ${ }^{\mathrm{TM}} 37$ Component FAME Mix). For analysis, the following operational settings were used: "split" injection mode, with a split ratio of 1:100; 1 $\mu \mathrm{L}$ injection volume; detector and injector temperature of $260{ }^{\circ} \mathrm{C}$; temperature increase of $4{ }^{\circ} \mathrm{C} \min ^{-1}$ up to $140^{\circ} \mathrm{C}$ for five minutes; heating ramp of $4{ }^{\circ} \mathrm{C} \min ^{-1}$ up to $240{ }^{\circ} \mathrm{C}$ for 30 minutes; and redissolution in $0.5 \mathrm{~mL}$ of $\mathrm{n}$-hexane. Obtained the chromatograms, the identification of fatty acids was determined by comparison with the standard and calculated the relative percentage of the total peak area.

Tocopherols ( $\alpha-, \beta$ - and $\delta$-) were analyzed according to the determinations of the Food Analytical Chemistry Methods (Wrolstad, 2003). After esterification, $0.01 \mathrm{~mL}$ of the mobile phase, consisting of ethyl acetate: acetic acid: hexane (1:1:198 $\mathrm{v} / \mathrm{v} / \mathrm{v})$ was added, shaken for 30 seconds to redissolve the extract and transferred to the vial. From each sample, $20 \mu \mathrm{L}$ was injected into a silica column (Supelcosil LC-Si - $250 \mathrm{x}$ $4.6 \mathrm{~mm}$, Supelco Inc.) coupled to a Shimadzu SPD-10A high performance liquid chromatograph (HPLC). Detection was monitored at $295 \mathrm{~nm}$. The tocopherols were identified by comparing their retention times with those of pure standards of $\alpha$-, $\beta$ - and $\delta$ - tocopherol and were quantified based on peak areas of the unknowns compared to those of pure standards (Sigma Chemical Co.).

The statistical procedure was completely randomized design, with four replicates for the determinations of seed quality and three replicates for the other tests. A $2 \times 3 \times 5$ factorial scheme was used, corresponding to two cultivars (BRS Green and BRS $187-8 \mathrm{H}), 3$ temperatures $(10,25$ and $\left.30^{\circ} \mathrm{C}\right)$ and five storage periods $(0,90,180,270$ and 360 days). The variables analyzed were subjected to testing for normality of error and homogeneity of variance, and the data were subjected to regression analysis for quantitative comparisons of data and means (Scott-Knott) for qualitative data at a $5 \%$ level of significance.

\section{Results and Discussion}

The water content of seeds during storage in different temperature conditions ranged from 7.1 to $10.3 \%$. The variation in seed water content was from $0.9 \%$ at $10{ }^{\circ} \mathrm{C} ; 2 \%$ at $25^{\circ} \mathrm{C}$ and $2.5 \%$ at $30^{\circ} \mathrm{C}$ at the time of evaluations (Table 1). It occurred in function of the hygroscopic equilibrium between seeds and relative humidity. Variations during storage period were greater in higher temperatures.
Table 1. Seed water content from cotton cultivars BRS Green and CNPA 1878 - $\mathrm{H}$ during storage at different temperatures $\left(10^{\circ} \mathrm{C}, 25^{\circ} \mathrm{C}\right.$ and $\left.30^{\circ} \mathrm{C}\right){ }^{(1)}$

\begin{tabular}{crcc}
\hline \multirow{2}{*}{ Storage (days) } & \multicolumn{3}{c}{ Temperature $\left({ }^{\circ} \mathrm{C}\right)$} \\
\cline { 2 - 4 } & \multicolumn{3}{c}{25} \\
\cline { 2 - 4 } Water content $(\%)$ \\
\hline 0 & $9.5 \mathrm{aA}$ & $9.5 \mathrm{aA}$ & $9.5 \mathrm{aA}$ \\
90 & $9.6 \mathrm{aA}$ & $9.6 \mathrm{aA}$ & $9.6 \mathrm{aA}$ \\
180 & $9.9 \mathrm{aA}$ & $7.6 \mathrm{aB}$ & $7.1 \mathrm{aC}$ \\
270 & $10.3 \mathrm{aA}$ & $8.7 \mathrm{aB}$ & $8.3 \mathrm{aC}$ \\
360 & $9.4 \mathrm{aA}$ & $8.9 \mathrm{aB}$ & $9.2 \mathrm{aA}$ \\
\hline CV (\%) & \multicolumn{3}{c}{2.45} \\
\hline
\end{tabular}

(1) Means followed by the same lowercase letters in rows and uppercase letters in columns do not differ according to the Scott-Knott cluster test at the 5\% level of significance.

Seed deterioration rate depends on temperature and seed water content because with increased respiration decrease seed reserves content necessary to germination (Ferreira and Borghetti, 2004), especially in seeds with water content above 13\% (Zuchi et al., 2011). In this research there were not changes in water content that could compromise physiological quality of seeds stored under different conditions.

In general, there was a reduction in the vigor of cottonseeds as evaluated by first germination count during storage (Figure 1). Vigor losses were more evident in seeds of 'BRS Green'. Seeds of cultivar BRS 187 - 8H showed subtle vigor losses when stored at $10{ }^{\circ} \mathrm{C}$ (Figure 1).

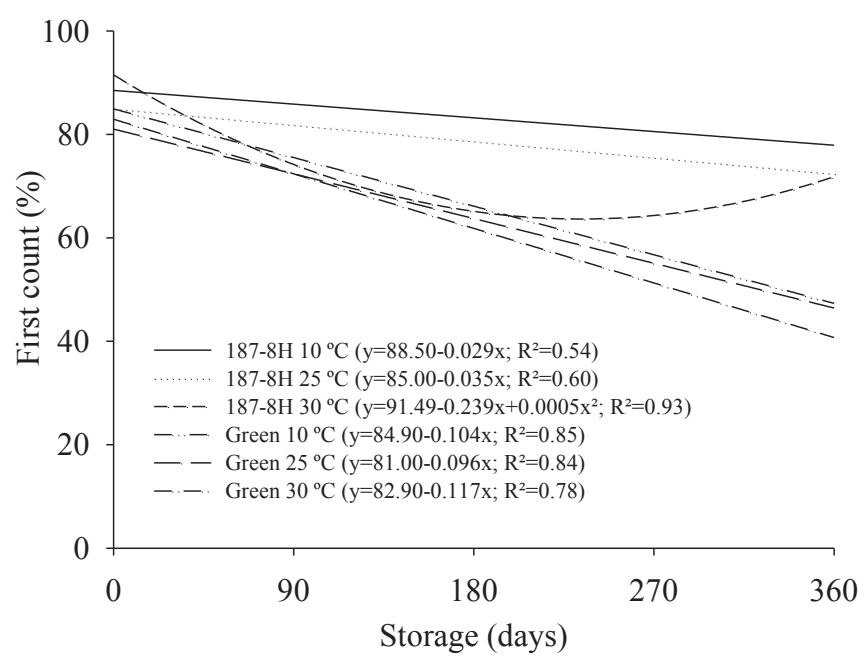

Figure 1. Germination at first count of BRS Green and BRS 187 - $8 \mathrm{H}$ cotton seeds stored for 360 days under different environmental conditions $\left(10,25\right.$ and $\left.30^{\circ} \mathrm{C}\right)$. 
Cotton seeds with white fibers showed higher germination levels than those seeds with colored fibers, regardless of storage environment (Figure 2A). Regarding storage conditions, temperatures above $25{ }^{\circ} \mathrm{C}$ accelerate the seed deterioration (Figure 2B).

Seed physiological quality evaluated by emergence was decreased during storage (Figure 3A) except when was maintained at $10{ }^{\circ} \mathrm{C}$ (Table 2). Furthermore, the greater emergence was observed for 'BRS 187-8H' seeds (Table 3). Based on these results can be affirmed that the rate of deterioration depends on initial seed physiological quality and environmental conditions (Walters et al., 2010). When seeds are kept at higher temperatures, deterioration is more intense due to lipid peroxidation, which cause damages in cellular membrane system, thus reducing seed viability and vigor (Schwember and Bradford, 2010). According with Lins et al. (2014) the deterioration of oil seeds can occur when the seed mass is heated. This heat occurs when increased moisture levels result in respiration of seeds and its associated microorganisms.
A

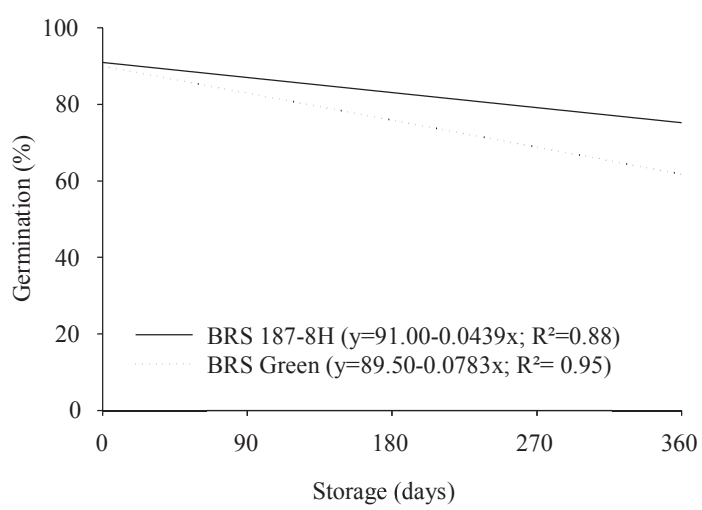

B

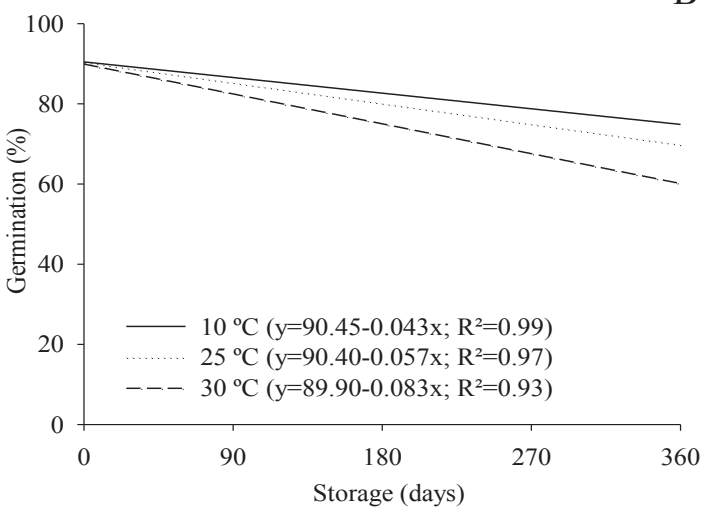

Figure 2. Germination (\%) of cotton seeds from cultivars BRS Green and BRS $187-8 \mathrm{H}$ (A) under different conditions (B) during storage.
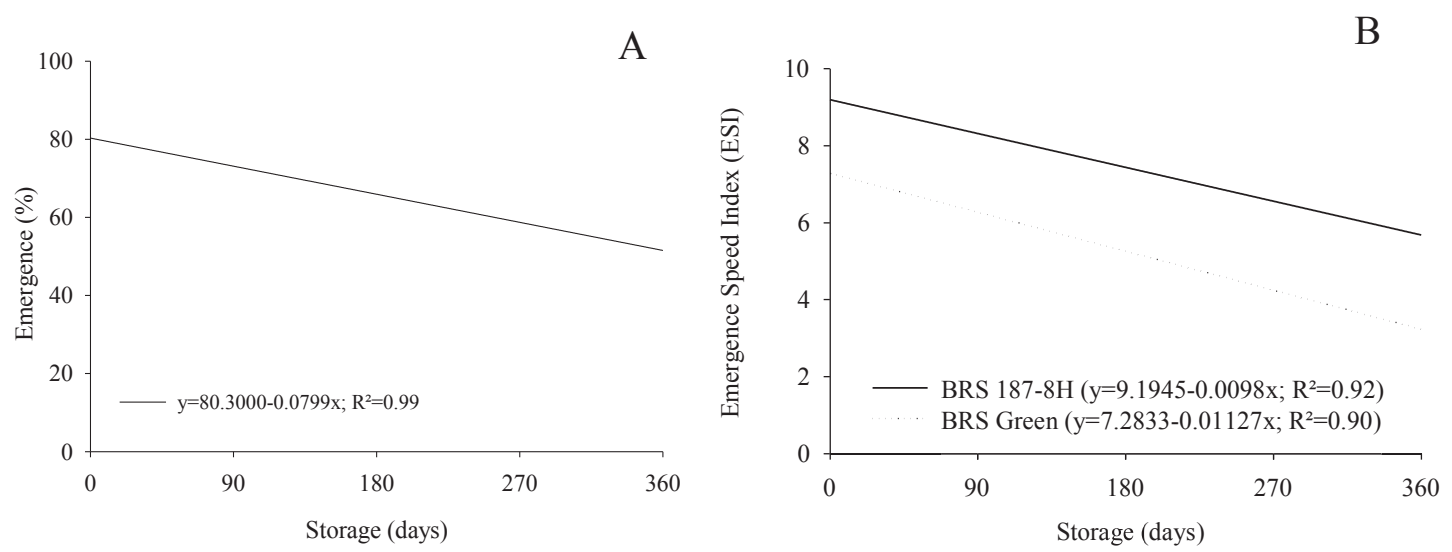

Figure 3. Percentage and speed of seedling emergence of cotton cultivars BRS Green and BRS 187 - 8H during storage.

Seedling emergence rate decreased during storage for both cultivars, regardless of the storage conditions (Figure 3B). It is also evident that seeds of the cultivar with white fibers had greater vigor than seeds of the colored fibers. Loss of vigor, evaluated by emergence speed index, is usually associated with the degree of seed deterioration, as observed for germination test and first germination count. Cotton seeds deteriorate rapidly during storage, mainly due to the activity of microorganisms associated to seeds and the high seed oil content (Freitas et al., 2004), resulting in a low storability.

Although seeds of both cultivars were produced under the same conditions and possessed narrow differences in initial physiological quality (Figures 1, 2 and 3) there was different behavior between these materials during storage. This probably is due the genetic differences, seed chemical composition and tolerance to storage, affecting the intensity of seed deterioration. 
Table 2. Seedling emergence of cotton cultivars BRS Green and BRS $187-8 \mathrm{H}$ during storage at different temperatures ${ }^{(1)}$.

\begin{tabular}{cc}
\hline Storage condition & Emergence (\%) \\
\hline $10^{\circ} \mathrm{C}$ & $76 \mathrm{a}$ \\
$25{ }^{\circ} \mathrm{C}$ & $70 \mathrm{~b}$ \\
$30{ }^{\circ} \mathrm{C}$ & $67 \mathrm{~b}$ \\
\hline $\mathrm{CV}(\%)$ & 12.93 \\
\hline
\end{tabular}

${ }^{(1)}$ Means followed by the same letter do not differ by the scott-knott cluster test at the $5 \%$ level of significance.

Results of sanitary quality tests during storage revealed greater incidence of Fusarium sp., Aspergillus niger and Penicillium sp. Reduced incidence of Fusarium sp. was observed in first 180 days of storage, with a subsequent increase until the end of storage (Figure 4A). For A. niger,

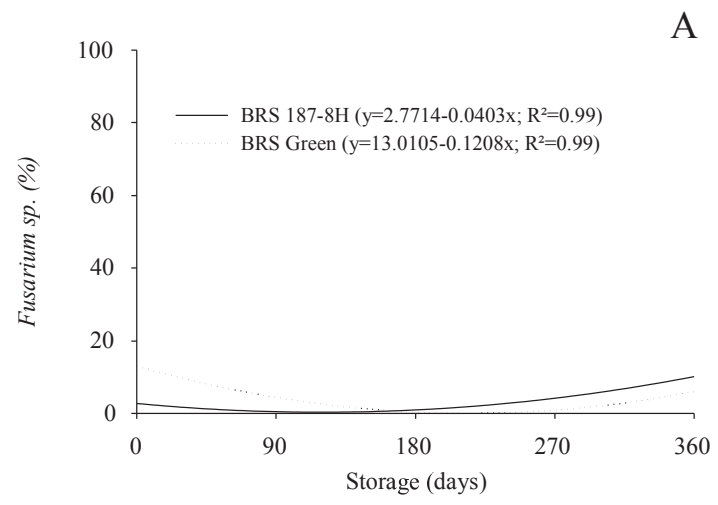

Table 3. Emergence for cotton cultivars BRS Green and BRS $187-8$ H during storage ${ }^{(1)}$.

\begin{tabular}{cc}
\hline Cultivar & Emergence (\%) \\
\hline Green & $61 \mathrm{~b}$ \\
$187-8 \mathrm{H}$ & $71 \mathrm{a}$ \\
\hline $\mathrm{CV}(\%)$ & 12.93 \\
\hline
\end{tabular}

(1) Means followed by the same letter do not differ by the Scott-Knott cluster test at the $5 \%$ level of significance.

there was an increase in incidence throughout storage, with a greater incidence in the cultivar BRS Green (Figure 4B). It is clear that the incidence of Aspergillus niger and Penicillium spp. was higher for the cultivar BRS Verde, regardless of the storage environment (Table 4).

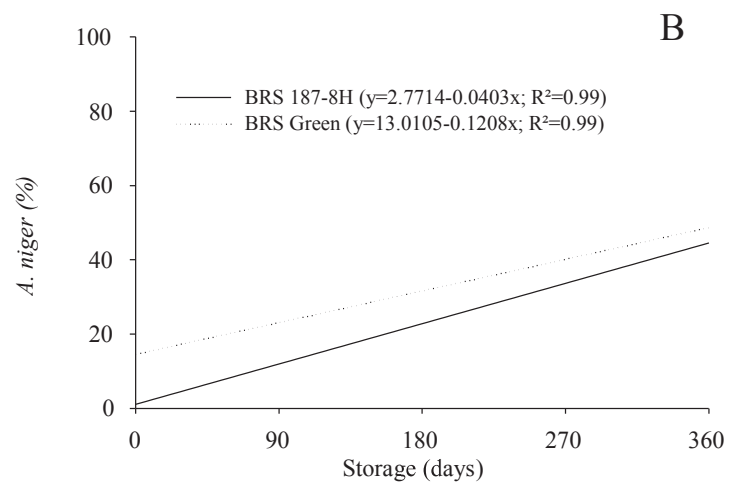

Figure 4. Incidence of Fusarium sp. and Aspergillus niger in cotton seeds, cultivars BRS Green and BRS 187 - 8H during storage.

Table 4. Incidence of Aspergillus niger and Penicillium spp. in cotton seeds of cultivars BRS Green and BRS 187 - $8 \mathrm{H}$ under different storage conditions ${ }^{(1)}$.

\begin{tabular}{|c|c|c|}
\hline \multirow{2}{*}{ Storage condition } & BRS Green & BRS $187-8 \mathrm{H}$ \\
\hline & \multicolumn{2}{|c|}{ A. niger } \\
\hline & \multicolumn{2}{|c|}{-------------------\%o------------------- } \\
\hline $10{ }^{\circ} \mathrm{C}$ & $30 \mathrm{aA}$ & $7 \mathrm{bA}$ \\
\hline $25^{\circ} \mathrm{C}$ & $31 \mathrm{aA}$ & $8 \mathrm{bA}$ \\
\hline $30{ }^{\circ} \mathrm{C}$ & $30 \mathrm{aA}$ & $13 \mathrm{bA}$ \\
\hline CV $(\%)$ & \multicolumn{2}{|c|}{27.89} \\
\hline \multirow{3}{*}{ Storage condition } & BRS Green & BRS $187-8 \mathrm{H}$ \\
\hline & \multicolumn{2}{|c|}{ Penicillium } \\
\hline & \multicolumn{2}{|c|}{---------------------- \% } \\
\hline $10^{\circ} \mathrm{C}$ & $26 \mathrm{aA}$ & $5 \mathrm{bA}$ \\
\hline $25^{\circ} \mathrm{C}$ & $20 \mathrm{aA}$ & $5 \mathrm{bA}$ \\
\hline $30{ }^{\circ} \mathrm{C}$ & $14 \mathrm{aB}$ & $7 \mathrm{bA}$ \\
\hline $\mathrm{CV}(\%)$ & \multicolumn{2}{|c|}{38.46} \\
\hline
\end{tabular}

(1)Means followed by the same lowercase letters in rows and uppercase letters in columns do not differ by the Scott-Knott cluster test at the $5 \%$ level of significance.
Lipids are the major reserve compounds of cottonseeds. The reduction in their content during storage is related to lipid oxidation that occurs during deterioration, caused by constant action of oxygen to form hydroperoxides, other oxygenated fatty acids and free radicals that accumulate in seeds during seed germination, secondary toxic products are formed, resulting in declines of seed vigor (Freitas et al., 2006). Due to the presence of double bonds makes unsaturated fatty acids prone to oxidation, a reaction between unsaturated fatty acids (regardless of whether they are in their free state or esterified in a triacylglycerol molecule) and oxygen. It is well known that the rate of oxidation increases with the increase in oxygen concentration and the length of storage period. Oil oxidation requires the presence of atmospheric oxygen. This can be reason to explain why the oil percentage of stored seeds to decreased during storage.

The lipid content in cottonseeds changed during storage, and this change varied among storage environments (Figure 5). 
Note that for 'BRS $187-8 \mathrm{H}$ ' seeds maintained at $30^{\circ} \mathrm{C}$, the lipid content decreased faster than for 'BRS Verde' seeds stored under the same conditions. During storage of oily species was observed declining of total oil content and seed germination. Quality parameters of seed such as oil content, fatty acid composition and protein content are significantly influenced by storage conditions and time (Ghasemnezhad and Honermeier, 2007). The observed conflict in oil content of different cultivars stored under differents temperature conditions is not clear. Our results are in confirmation with Ghasemnezhad and Honermeier, 2007) in sunflower seeds, who reported that there was not clear variation tendency in sunflower seed oil percentage with storage temperature.

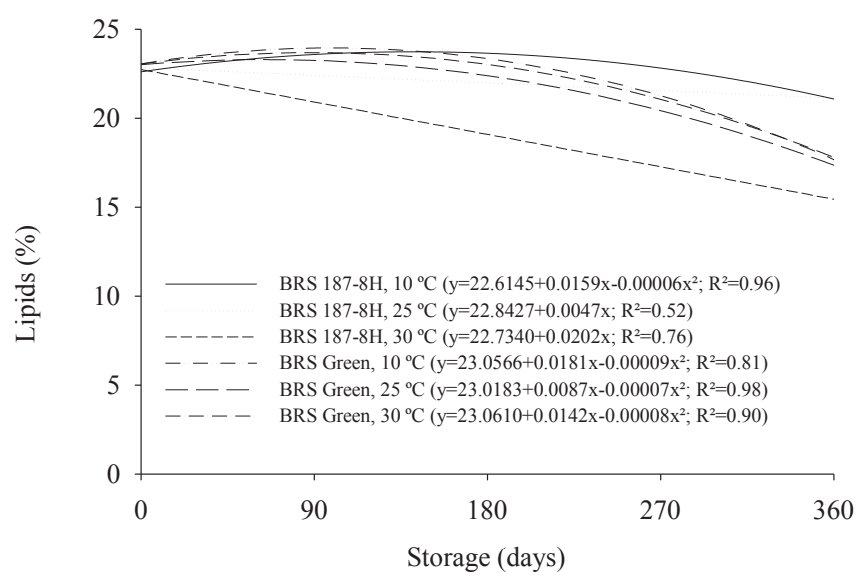

Figure 5. Lipid content of cotton seeds, cultivars BRS Green and BRS 187 - 8H stored under different environmental conditions.

Oxidation of the lipid compounds in cottonseeds can increase oil acidity, as a consequence of deterioration accelerating. In the present study, increases in free acidity and peroxide index were observed in cotton seeds during storage (Figures 6 A and B). Seeds of 'BRS Verde' reached higher peroxide index values than BRS 187-8H (Figure 6 B). These results are consistent with those of germination and vigor, as evaluated by speed of seedling emergence and the incidence of storage fungi, both showing lower results for BRS, thus increasing the acidity and concentration of peroxides in the seeds.

The main causes for the rapid deterioration of oilseeds are lipid peroxidation and the increased content of free fatty acids during storage (Balešević-Tubić et al., 2007). These results confirm the assumption that the storage period affects seed deterioration by causing a reduction in reserve compounds, a phenomenon that has also been observed in other oilseed species, such as soybean and sunflower (Balešević-Tubić et al., 2005, Sharma et al., 2011).

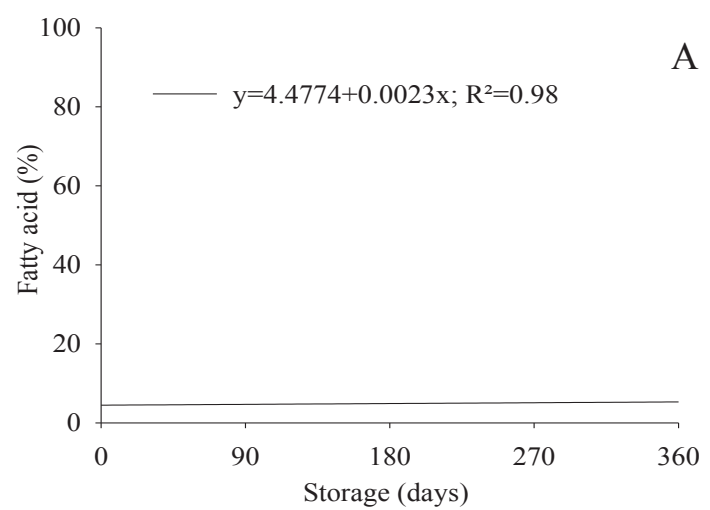

A

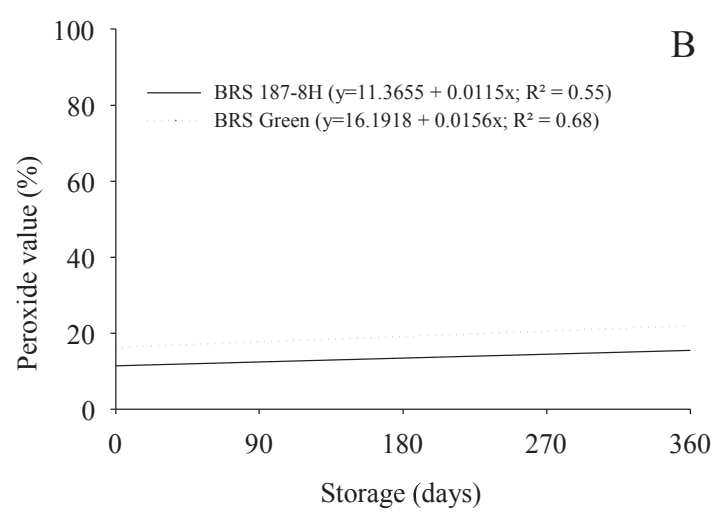

Figure 6. Free acidity (A) and peroxide index (B) of the oil contained in cotton seeds, cultivars BRS Green and BRS 187 - 8H during storage.

In general, there was a decrease in the concentration of fatty acids with the progress of seed aging, with the most marked decreases in unsaturated fatty acids such as oleic (Figure 7C) and linoleic fatty acids (Figure 7D). The reduction in fatty acid concentration was greater in seeds stored at temperatures of $25^{\circ} \mathrm{C}$ and $30^{\circ} \mathrm{C}$.

The chemical stability of lipids is crucial for the performance of oilseeds because the effects of the instability caused by free radicals leads to lipid peroxidation and oxidative stress, accelerating the seeds' deterioration (José et al., 2010). These biochemical markers may provide information about seed natural ageing (Soares et al., 2005) because the presence of free fatty acids damages cell membranes, particularly in mitochondria, thus reducing energy production, and lipid peroxidation strongly affects the energy conversion necessary for germination and can also damage DNA (Iqbal et al., 2002).

Cottonseeds showed higher proportion of linoleic acid than others fatty acids. This compound, due to its unsaturation, 
is more susceptible to deterioration than other fatty acids (Goel and Sheoram, 2003). In the most of seed species that are high concentration of oil and levels of oleic (18:1),

A

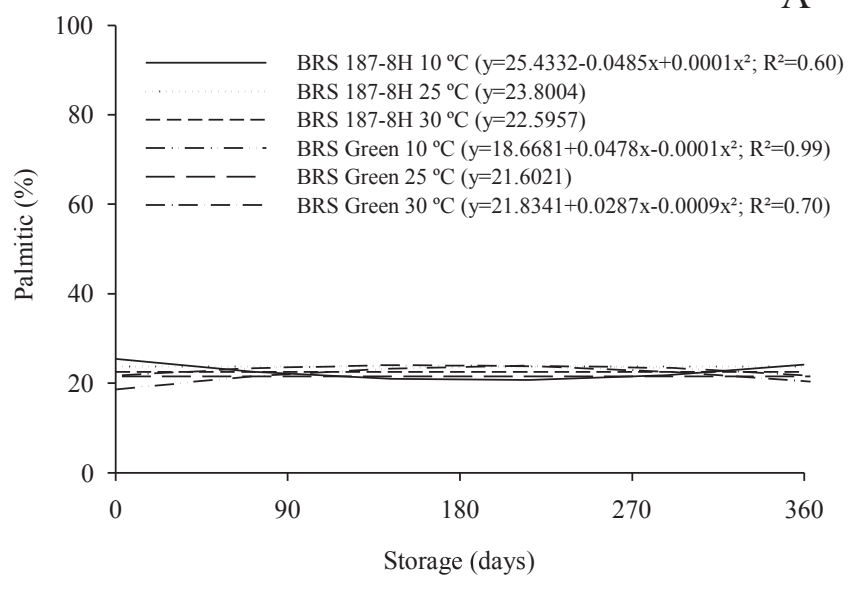

$\mathrm{C}$

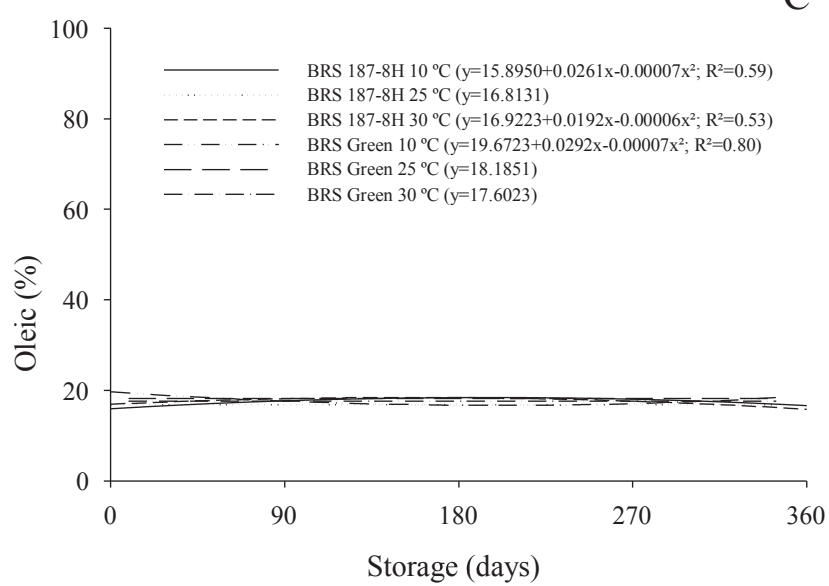

linoleic (18:2) and linolenic (18:3) acid, as cotton, are more prone to deterioration than seeds with high levels of saturated fatty acids (Balešević-Tubić et al., 2007).

B

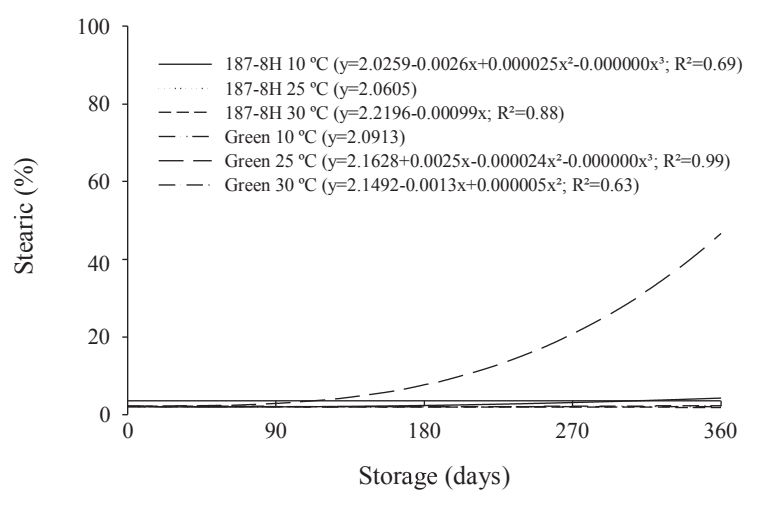

$\mathrm{D}$

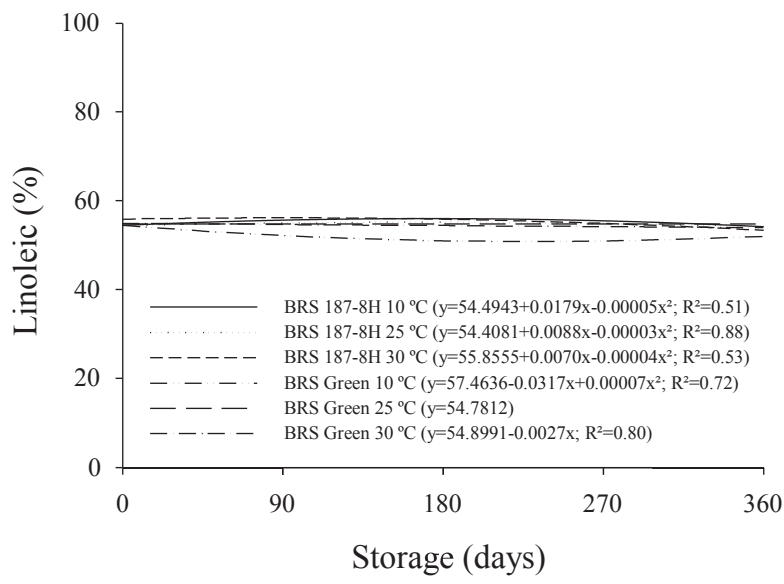

Figure 7. Levels of palmitic (A), stearic (B), oleic (C) and linoleic (D) fatty acids in the oil contained in cotton seeds, cultivars BRS Green and BRS 187 - 8H during storage under different environmental conditions.

In oil seeds, decreases of physiological quality during aging have been observed and associated with antioxidant activities and antioxidant compounds (Ávila et al., 2012). The cotton seeds contain tocopherol, a natural antioxidant that can influence scavenge lipid peroxy radicals and yield a tocopheroxyl radical that can be recycled back to the corresponding tocopherol by reacting with ascorbate or other antioxidants reducing the level of deterioration during storage. In this study the levels of $\alpha-, \beta-$, $\delta$ - and total tocopherol were measured and the concentration of this compound changed during storage, as shown in Figure 8.

An interesting finding of this study is that tocopherol content also depends on the cultivar. With the exception of $\alpha$-tocopherol, seeds with colored fibers had higher antioxidant levels than those with white fibers (Figure 8). There was a decreasing trend of tocopherol content with the increasing storage time regardless of conditions which the seeds were stored. This reduction is observed most clearly in seeds maintained at $25^{\circ} \mathrm{C}$ and $30{ }^{\circ} \mathrm{C}$ (Figure 9).

Tocopherol plays an important role in protecting oilseeds to reduce the peroxides and superoxides levels and also inhibiting the lipid peroxidation, preventing the oxidative stress. When seeds are subjected to severe stress there is a significant increase in lipid peroxidation and the decrease in tocopherol production resulting in the deficiency of antioxidant which is not balanced by another protective mechanism, thus causing the reduction of compounds in the seed (Giurizatto et al., 2012). This fact coincide with the observed in present study which resulted in a significant antioxidant loss during storage.

In the present study, the levels of tocopherol associated with the lipid content are particularly sensitive to changes 
in the acting of cottonseeds of both studied cultivars as observed in the seed germination and vigor and even in the physicochemical properties of the oil. This antioxidant despite the beneficial effects, including inhibiting lipid degradation

A
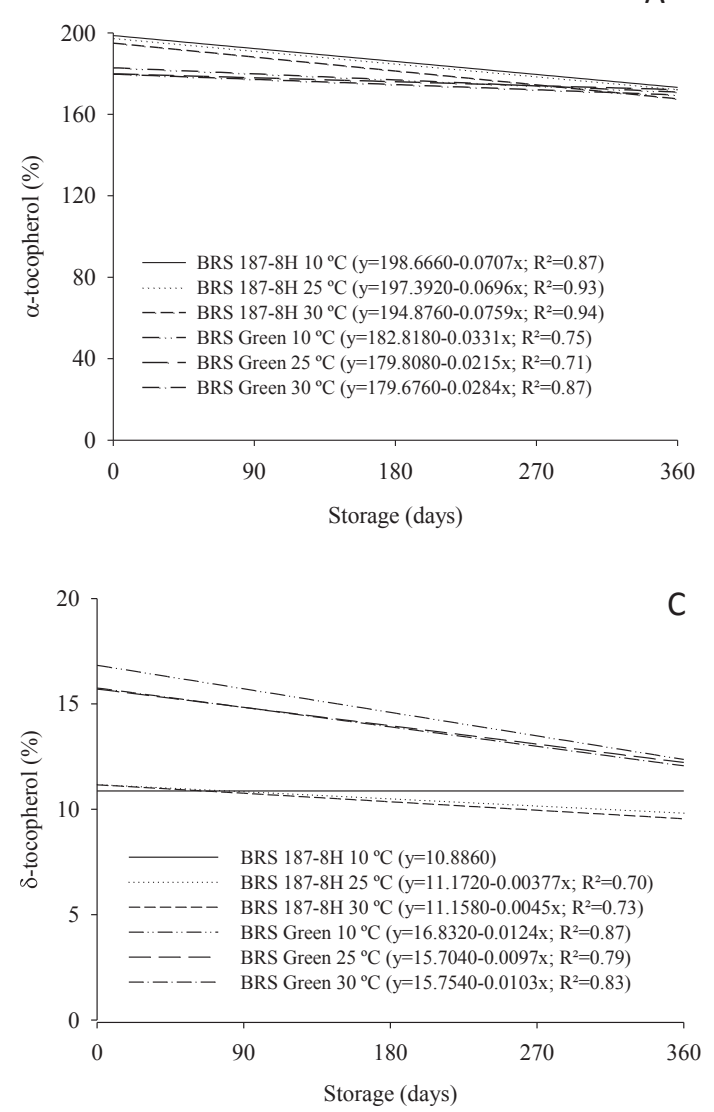

and limiting non-enzymatic oxidation during storage, was not sufficient to decrease the progression of seed deterioration. However, this type of analysis may be promising for detecting the deterioration level of cottonseeds stored.
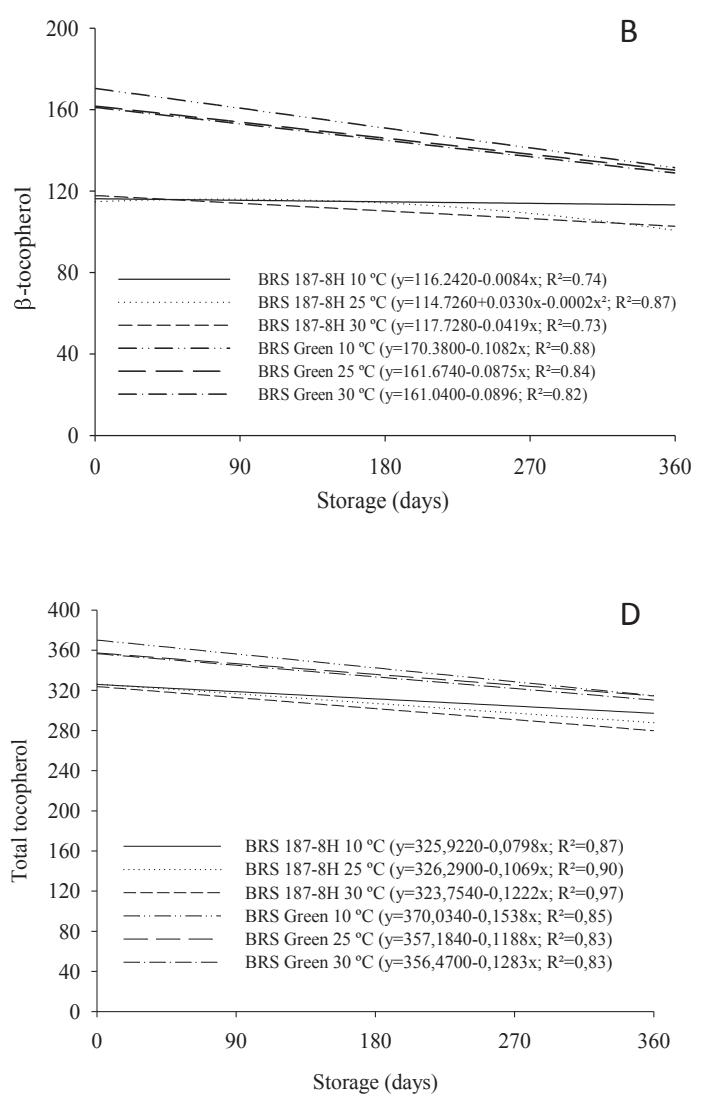

Figure 8. Levels of $\alpha-(A), \beta-(B), \delta-(C)$ and total tocopherol (D) in the oil contained in cotton seeds, cultivars BRS Green and BRS 187 - 8H during storage under different environmental conditions.

\section{Conclusions}

The cottonseeds physiological potential is reduced at day 90 particularly when the storage is carried out at 25 to $30^{\circ} \mathrm{C}$.

Changes in lipid content and tocopherol are associated with the reduction of physiological quality. At temperatures above $25{ }^{\circ} \mathrm{C}$ the deterioration of cottonseeds is improved and decreases their physiological quality.

The loss quality during storage is related to a reduction in fat content and tocopherol and also on the increase in acidity and peroxide.

\section{Acknowledgements}

The authors thank the general manager of Embrapa Algodão, Napoleão Esberard de Macêdo Beltrão (in memoriam), for providing the seeds used to conduct the study, the National Council for Scientific and Technological Development (Conselho Nacional de Desenvolvimento Científico e TecnológicO - CNPq) for granting a fellowship to the first author and funding for the project, the Brazillian Federal Agency for the Support and Evaluation of Graduate Education (Coordenação de Aperfeiçoamento de Pessoal de Nível Superior - CAPES) and FAPEMIG for providing research assistance.

\section{References}

AOAC - Association of Official Analytical Chemists. Official methods of analysis. International, 16.ed, 1995, v.2. 559p.

AOCS. American Oil Chemists' Society. Official Methods and Recommended Practices of the American Oil Chemists' Society, 4ed, 1990, p. 8-53. 
ÁVILA, M. R.; BRACCINI, A.L.; SOUZA, C. G. M.; MANDARINO, J.M.G.; BAZO, G. L.; CABRAL, Y. C. F. Physiological quality, content and activity of antioxidants in soybean seeds artificially aged. Revista Brasileira de Sementes, v.34, n.3, p.397-407, 2012. http://www.scielo.br/scielo. php?pid=S0101-31222012000300006\&script=sci_arttext

BALEŠEVIĆ-TUBIĆ; S.; TATIĆ, M.; MILADINOVIĆ, J.; PUCAREVIĆ, $M$. Changes of fatty acids content and vigour of sunflower seed during natural aging. Helia , v.30, n.47, p. 61-67, 2007. <http://www.doiserbia.nb.rs/img/ doi/1018-1806/2007/1018-18060747061B.pdf>

BALEŠEVIĆ-TUBIĆ, S.; MALENCIC, D.; TALIĆ, M.; MILADINOVIĆ, $\mathrm{J}$. Influence of ageing process on biochemical changes in sunflower seeds. Helia, v.28, n. 42, p.107-114, 2005. <http://www.doiserbia.nb.rs/img/ doi/1018-1806/2005/1018-18060542107B.pdf>

BRASIL. Ministério da Agricultura, Pecuária e Abastecimento. Regras para análise de sementes. Ministério da Agricultura, Pecuária e Abastecimento. Secretaria de Defesa Agropecuária. Brasília: MAPA/ACS, 2009, 395p. http:// www.agricultura.gov.br/arq_editor/file/2946_regras_analise_sementes.pdf

FERREIRA, A.G.; BORGHETTI, F. Germinação: do básico ao aplicado. Artmed, Porto Alegre, 2004, 323p.

FREITAS, R.A.; DIAS, D.C.F.S.; DIAS, L.A.S.; OLIVEIRA, M.G.A.; JOSÉ, I.C. Alterações fisiológicas e bioquímicas em sementes de algodão submetidas ao envelhecimento artificial. Bioscience Journal, v.22, p. 67-76, 2006. <http://www.seer.ufu.br/index.php/biosciencejournal/article/ view/6641/4368>

FREITAS, R.A.; DIAS, D.C.F.S.; DIAS, L.A.S.; OLIVEIRA, M.G.A. Testes fisiológicos e bioquímicos na estimativa do potencial de armazenamento de sementes de algodão. Revista Brasileira de Sementes, v.26, p.84-91, 2004. $<$ http://www.scielo.br/pdf/\%0D/rbs/v26n1/a13v26n1.pdf $>$

GHASEMNEZHAD, A.; HONERMEIER B. Influence of storage conditions on quality and viability of high and low oleic sunflower seeds. International Journal of Plant Production, v.3, p.41-45, 2007. http://www.sid.ir/EN/ VEWSSID/J_pdf/124220090406.pdf

GIURIZATTO, M.I.K.; FERRARESE-FILHO, O.; FERRARESE, M.L.L.; ROBAINA, A.D.; GONÇALVES, M.C.; CARDOSO, C.A.L. $\alpha$-Tocopherol levels in natural and artificial aging of soybean seeds. Acta Scientiarum Agrononomy, v. 34, p. 339-343, 2012. <http://www.scielo.br/scielo. php?pid=S1807-86212012000300015\&script $=$ sci_arttext $>$

GOEL, A.; SHEORAM, I. S. Lipid peroxidation and peroxide-scavenging enzymes in cotton seeds under natural ageing. Biologia Plantarum, v. 3, p. 429434, 2003.<http://link.springer.com/article/10.1023/A:1024398724076>

HARTMAN, L.; LAGO, R.C.A. Rapid preparation of fatty acid methyl esters from lipids. Laboratory and Practice, v. 22, p. 475-476, 1973.

IQBAL, N.; BASRA, S. M. A.; KHALIL-UR-REHMAN. Evaluation of vigour and oil quality in cottonseed during accelerated ageing. International Journal of Agriculture \& Biology, v. 4, p. 318-322, 2002. https://www. researchgate.net/publication/238067350
JOSÉ, S.C.B.R.; SALOMÃO, A.N.; COSTA, T.S.A.; SILVA, J.T.T.T.; CURI, C.C.S. Armazenamento de sementes de girassol em temperaturas subzero: aspectos fisiológicos e bioquímicos. Revista Brasileira de Sementes, v.32, p. 29-38, 2010. <http://www.scielo.br/pdf/rbs/v32n4/04.pdf>

LINS, S. R.O.; CARVALHO, M.L.M.; CARDOSO, M.G.; MIRANDA, D.H.; ANDRADE, J. Physiological, enzymatic, and microstructural analyses of sunflower seeds during storage. Australian Journal of Crop Science v.8, p.1038-1048, 2014.<.http://www.cropj.com/lins_8_7_2014_1038_1048.pdf>

MAGUIRE, J. D. Speed of germination-aid in selection and evaluation for seedling emergence and vigor. Crop Science, v. 2, p. 176-177,1962.

QUETTIER, A.; EASTMOND, P.J. Storage oil hydrolysis during early seedling growth. Plant physiology and Biochemistry, v. 47, n .6, p.485-490, 2009. <http://www.sciencedirect.com/science/article/pii/ S0981942808002416>

SATTLER, S.E.; GILLILAND, L.U.; MAGALLANES-LUNDBACK, M.; POLLARD, M.; DELLAPENNA, D. Vitamin E is essential for seed longevity and for preventing lipid peroxidation during germination. Plant Cell, v.16, p.1419-1432, 2004. <http://www.ncbi.nlm.nih.gov/pmc/articles/ PMC490036/pdf/tpc1601419.pdf>

SCHWEMBER, A.R.; BRADFORD, K.J. Quantitative trait loci associated with longevity of lettuce seeds under conventional and controlled deterioration storage conditions. Journal of Experimental Botany, v. 61, p.4423-4436, 2010. <http://jxb.oxfordjournals.org/content/early/2010/08/06/jxb.erq248. full.pdf + html $>$

SHARMA, S.; GULERIA, S.; GILL, B.S.; MUNSHI, S.K. Lipid accumulation in developing soybean: influence of seed position on stem axis. Genetic Plant Physiology, v.1, p.56-67, 2011. <http://www.bio21.bas.bg/ ippg/bg/wp-content/uploads/2012/02/GPP_1_1-2_56-67.pdf $>$

SOARES, T.A.; BIAGGIONI, M.A.M., FRANÇA-NETO, J.B. Análise da acidez graxa como índice de qualidade em grãos de soja. Energia na Agricultura, v. 20, p. 91-102, 2005. <http://revistas.fca.unesp.br/html/CD REVISTA_ENERGIA_vol1/vol20n12005/Artigos/Tatiane\%20Soares.pdf.

WALTERS, C.T.; BALLESTEROS, D.; VERTUCCI, V. Structural mechanics of seed deterioration: standing the test of time. Plant Science, v.179, p.565-573, 2010. <http://www.sciencedirect.com/science/article/pii/ S0168945210001846>

WROLSTAD, R.E. Analysis of tocopherols and tocotrienols. In: WROLSTAD, R.E. (ed) Current Protocols in Food Analytical Chemistry, p. 479-490, 2003.

ZUCHI, J.; SEDIYAMA, C.S.; LACERDA FILHO, A.F.; REIS, M.S.; FRANÇA-NETO, J.B.; ZANUNCIO, J.C.; ARAÚJO, E.F. Variação da temperatura de sementes de soja durante o armazenamento. Informativo Abrates, v. 22, p. 35-40, 2011. <http://www.alice.cnptia.embrapa.br/alice/ bitstream/doc/916892/1/32825.pdf> 